\title{
The Influence of Electronic Word of Mouth (E-WOM) And Travel Motivation toward the Interest in Visiting Lombok, Gender as a Mediator
}

\author{
Zakky Fahma Auliya, Imanda Firmantyas Putri Pertiwi \\ IAIN Surakarta, Indonesia \\ zakkyfahma@gmail.com, imanda.putri@iainsalatiga.ac.id
}

\begin{abstract}
The background of this research is the decreased number of tourists, either domestic or foreign tourists, visiting Lombok, in which Lombok is a halal tourism destination in Indonesia. This research aims to analyze the influence of electronic word of mouth (e-WOM) and travel motivation toward the interest in visiting Lombok with gender as the mediator, using a purpose-sampling technique on its sample collection. The respondents of this research are university students in Surakarta. The number of questionnaires spread by the researcher is 316 samples and the samples that can be used are 264. This research uses the analysis tool of SPSS 22 with a scale of 1-5. The result shows that e-WOM and travel motivation influence the interest in visiting Lombok, while the influence with gender as the mediator shows that males have a bigger influence toward the use of e-WOM and travel motivation toward the interest of visiting Lombok.
\end{abstract}

Keywords: E-WOM, Travel Motivation, The Interest Of Visiting Lombok, Gender

\begin{abstract}
Abstrak
Latar belakang masalah pada penelitian ini adalah adanya penurunan jumlah wisatawan baik wisatawan domestik maupun wisatawan mancanegara untuk berkunjung ke Lombok, dimana Lombok menjadi tujuan wisata halal di Indonesia. Penelitian ini bertujuan untuk menganalisis pengarub WOM elektronik dan motivasi berwisata terhadap minat berkunjung ke Lombok dengan Gender sebagai mediator dengan menggunakan teknik purpose sampling pada pengambilan sampelnya. Responden pada penelitian ini adalah mahasiswa yang kuliab di Surakarta. Peneliti menyebarkan kuesioner sebanyak 315 sampel, dan sampel yang bisa dipakai berjumlah 264. Menggunakan alat analisis SPSS 22 dengan skala pada penelitian ini antara 1-5. Hasil dari penelitian ini mengungkapkan babwa WOM elektronik dan motivasi berkunjung berpengarub terhadap minat berkunjung ke Lombok, sedangkan pengarubnya dimana gender sebagai mediator mengungkapkan bahwa laki-laki mempunyai berpengarub lebih besar pada penggunaan WOM elektronik dan motivasi berkunjung terhadap minat berkunjung ke Lombok.
\end{abstract}

Kata Kunci: E-WOM, Motivasi Berwisata, Minat Berkunjung ke Lombok, Gender

Permalink/DOI: https://doi.org/10.18326/infsl3.v13i2.201-218 


\section{Introduction}

Currently, halal tourism becomes an interesting to study due to its growth, and the reasons are Moslem population growth around the world (Battour \& Ismail, 2014), and the increased income of the middleclass countries with large Moslem population as well as young Moslem population (Mastercard \& CrescentRating, 2016). The consistent growth in the religious tourism segment has become a global trend (Jaelani, 2017b). Moreover, some countries with the majority of non-Moslems enliven this market. It can be seen in the result of the previous studies proving that it is not only the majority of Moslems applying halal tourism concept (Chanin, Sriprasert, Rahman, \& Don, 2015; Chookaew, Chanin, Charatarawat, Sriprasert, \& Nimpaya, 2015; Razzaq, Hall, \& Prayag, 2016). Therefore, in the end of the day, halal tourism does not only focus on religious tradition, but also other supporting facilities like restaurant and hotel that provide halal foods as well as solat place (Jaelani, 2017b).

Another market that is interesting to be paid attention is youth tourists,--who are differentiated in two groups, generation $\mathrm{Y}$ and $\mathrm{Z}$. It is an important segment in Moslem tourism industry with the average age is 23 years ( 7 years younger than the global average), which is $25 \%$ of the total number of tourists in the world (Mastercard \& CrescentRating, 2016) — where social media (in Pietro \& Pantano, 2013) and blog (Chen, Shang, \& Li, 2014) become a media to influence young tourists.

The previous studies have stated that the market of young tourists is interesting to study due to the fact that this market gives a new view about things that have not been used by the previous generation as a reference in choosing vacation places, but they are used by young tourists (Chen et al., 2014; di Pietro \& Pantano, 2013; Kreis \& Gottschalk, 2015; M. Lee \& Youn, 2009; Ting, Chiu, \& Kayat, 2015). Unlike the previous researches, in this research, the researcher conducts t-test to male and female respondents. Researches about halal tourism in Indonesia have been conducted by some researchers, such as (Asih \& Asih, 2015; Jaelani, 2016, 2017a; Prabowo, Rahman, Rahman, \& Samah, 2015). Lombok, as one of halal tourist destinations in Indonesia, also experiences economic development after being transformed into halal tourist destination ("West Nusa Tenggara Can Be Proud, the Number of Tourist Visit Has Reached 3 Million in 2016," 2016) although data on the growth of tourist visit, either domestic or foreign tourists, get stagnated (BPS, 2015, "West Nusa 
Tenggara Can Be Proud, the Number of Tourist Visit Has Reached 3 Million in 2016," 2016).

Stagnation in tourist visits to Lombok, either domestic or foreign tourists, is an interesting thing for the writer to conduct a research, where the previous researches state that halal tourism is very potential (Bhuiyan, Siwar, Ismail, \& Islam, 2011; Chookaew et al., 2015; Jaelani, 2016, 2017a; Mohsin, Ramli, \& Alkhulayfi, 2016). In fact, there is no increased number of tourists in such tourism in Lombok, either domestic or foreign tourists. This research's scope is only to analyze university students in Surakarta. The aim of this research is to find out how e-WOM and travel motivation attract youth Moslem tourists in Surakarta to visit Lombok, with gender variable as the mediator. This research gives contribution to increase knowledge about the interest in visiting halal tourism that has been developed by the previous researches.

\section{Literary Review}

Electronic Word of Mouth

Tourist interest to visit is influenced by many things such as attitude to tourist attraction and resources of tourist attraction (e-WOM) (Wang, 2015), founded by Tseng, Kou, \& Chen (2014) inform that e-WOM gives positive effect on the interest in transaction. In other way, e-WOM gives negative effect on the interest in transaction for people who are not virtual community member.

WOM is one of communication media, between people, about trusted and independent product and service, so there is no intervention from company (Reza Jalilvand \& Samiei, 2012). Currently, technology development makes everyone be able to do activities with others using internet and even to create virtual community that makes many people seemingly bound to each other so that they will trust each other's opinion and will (Alkailani, 2016). Additionally, their personal opinion will be ease to be accessed by global internet user community (Dellarocas, 2003).

Some of them are active in posting online reviews of online community with reasons that through the post, they will be useful for other people who need reviews made by fellow consumers, trusted by community members as a person who understand more -opinion leadership-, give solution to other people (Kreis \& Gottschalk, 2015). This WOM is helping each other among the community members, so it can 
be reference.

A research about WOM conducted by Kim, Jang, \& Adler (2015) with respondents from Gen Y or millennial generation, it is stated that youth can influence other consumers easily by sharing experience. However, it is important to manage WOM, either positive or negative ones. Mistakes during service to the consumers may trigger them to give negative comments on the company's website, blog, and online community (Shin, Song, \& Biswas, 2014). It is strengthened by a research conducted by Auliya, Umam, \& Prastiwi (2017) clarifying that e-WOM is still one of consumers' references.

Consumers, especially those who are engaged to the process of decision making (in this case is involving a lot of money) tend to read more in order to analyze more reviews more carefully (Filieri, 2016). It means that consumers know that there is a lot of information that can be obtained from internet, consumers are aware of e-WOM, and are able to filter the information to be made as personal conclusion of the e-WOM. E-WOM or usually called as online customer reviews is still become trusted information source for the consumers (Chou, 2012).

A research conducted by Pietro \& Pantano (2013) states that e-WOM becomes determinant of the young tourists' interest to visit. A research by Jalilvand, Ebrahimi, \& Samiei (2013) also reveal that e-WOM influence interest to visit halal destination. The same result comes from Abubakar \& Ilkan (2016) stating that e-WOM influence the interest to visit.

The researcher's opinion is e-WOM still becomes one of travelers' media to get information about tourist destination before starting their trip. In the previous research, for example, a research conducted by Reimer \& Benkenstein (2016) and Shao (2012), it dfferentiates the influence of positive WOM and negative WOM. In this research, the researcher does not differentiate them, because both of the types of WOM become travelers' way to know better about toruist destination. It means that e-WOM influences the interest to visit Lombok.

\section{Travel Motivation}

Travel motivation, based on previous researches, has answered a questions of why people are triggered to travel or to go to tourist attraction (Almuhrzi \& Mohammed, 2017; Bai \& Hu, 2009; Duman, 2011; 
Geng, Long, Chen, \& Li, 2017; Konu \& Laukkanen, 2009). A research conducted by Khan, Chelliah, \& Ahmed (2017) explains, in detail, about female traveler. It is stated that high travel motivation is influenced by an interest to know about new culture, places, knowledge as well as an interest to relax, to adventure, and to get entertained. It is important to understand tourists' behavior, and, specifically, their travel motivation in order to develop product quality, better marketing strategy, better service approach, and competition (Vuuren \& Slabbert, 2011).

Developing suitability between time perspective and travel motivation is necessary to increase the interest to visit. Specifically, using advertisement manipulating perspective that gets oriented to this present time, motivation to seek for sensation, such as interesting tourist attraction, is necessary to be highlighted. Conversely, using advertisement manipulating future perspective, it is important to emphasize the increase of knowledge (Lu, Hung, Wang, Schuett, \& Hu, 2016).

There are two main factors in psychological factor, that is, pull and push factors (Tsai, Sakulsinlapakorn, \& Council, 2016). Push factors are: (1) being comfortable in new place, (2) embracing new experience from new place, (3) learning new culture, (5) willingness to see other's way of life of which culture is different from us, (6) seeing scenery of tourist attraction, (8) meeting new people, (9) being bored with routine activity, and (10) looking for sensation and joyful.

Pull factors are: (1) the existence of special event in the tourist attraction, (2) extraordinary impression of the tourist attraction, (3) fine foods, (4) friendly and polite people in the tourist attraction, (5) being participated in festival that will give unique experience, (6) good service in the tourist attraction, (7) culture, art, and tradition of the tourist attraction, (8) comfort in family tourism, (9) comfortable tourist attraction. A study conducted by Konu \& Laukkanen (2009) gives general description about what things that motivate tourist to travel.

Therefore, the result gives perspective about travel motivation, not the motivation to visit certain tourist attraction. It is important to know about it because travel motivation of people with different nationalities can be different as well. The result is the understanding of the main motivation of tourists as well as itinerary that is match to the tourist interest are important (Whang, Yong, \& Ko, 2015). Different from a research 
conducted by Bai \& Hu (2009), on which the object of the research is generation $\mathrm{X}$, while the object of this research is generation $\mathrm{Z}$.

\section{Gender as Mediator}

Social role theory states that gender difference in social behavior comes from a shared view that about the proper behavior for men and women (Karakowsky \& Elangovan, 2001). Expression of risk varies in gender; women tend to be feminine while men tend to be masculine, for example (Meyers-Levy \& Loken, 2015). Based on those two research results, it can be proven that men and women have different behavior, and they also have differences during risk taking.

J. H. Lee, Kim, Ko, \& Sagas (2011) states that for women, representative physical factor, cleanliness, and appearance of the staff become important things to pay attention. Therefore, it is necessary to have segmentation from market and different strategy for segmentation based on gender.

A research conducted by M.-J. Kim, Lee, \& Chung (2013), where gender as moderation variable also strengthens the fact that the effects of gender influence different things between men and women, that it is explained that men have different preference compared to women. Therefore, it has not been known yet what things influence men and women. This research result is strengthened by a research conducted by (A Mohammed Abubakar, Ilkan, \& Al-tal, 2017; Karakowsky \& Elangovan, 2001; M.J. Kim et al., 2013; Meyers-Levy \& Loken, 2015).

Different research result (Lin, 2014) states that Gender does not give different influence on the analyzed variables. Gender differences are not differentiator in decision making, especially during travelling. This research has different view from other researches, about stereotypes of gender difference.

The differences are interesting for the researcher to use gender variable as mediator of the analyzed variables. 
Research Model

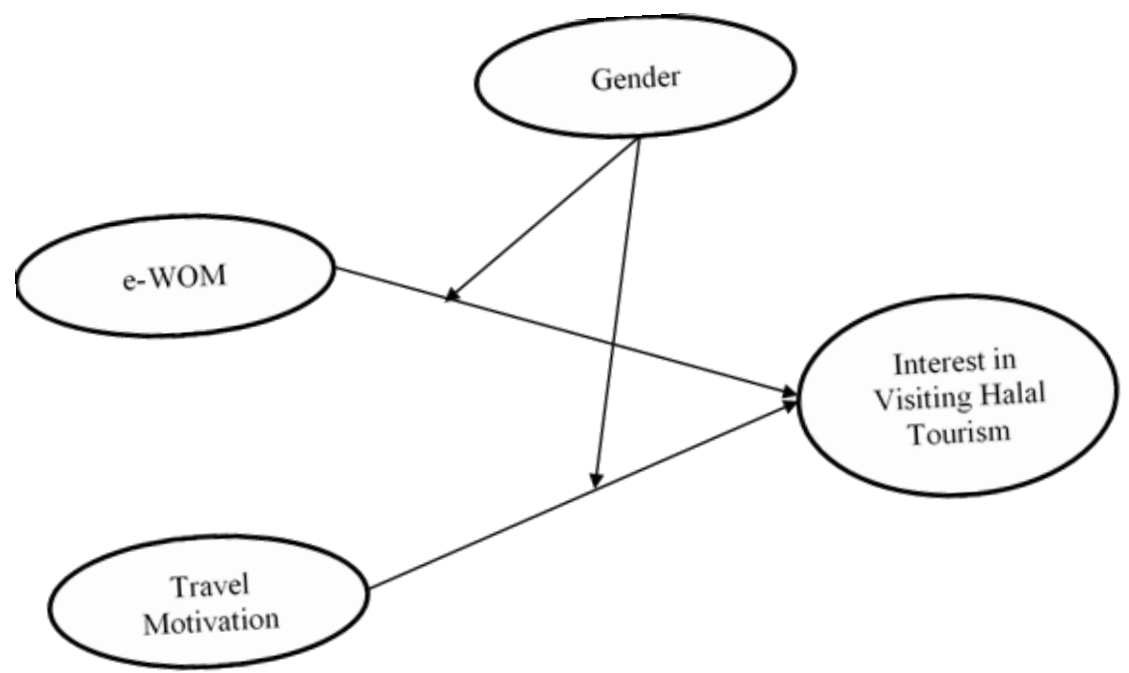

\section{Research Method}

Procedure of Data and Sample Collection

This research area covers ex-residency of Surakarta. Population of this research is university students in Surakarta that have not visited Lombok. Questionnaires of this research are spread using accidental method, and the number of questionnaires is 380 , and only 345 questionnaires back. From 345 questionnaires that are back and complete, there are only 323 that can be used. In this research, the questionnaires that are normal and pass the test of classical assumption are 264 respondents. According to the researcher, that number is the minimal number of sample used in research, if it is referred to Ferdinand (2014).

\section{Measurement}

The researcher makes a measurement in the form of indicator of each variable in this research. Indicator of this variable is made by adapting indicators of the previous researches with relevant adjustment for this research. On e-WOM variable, the researcher writes six indicators as the measurer. Meanwhile, travel motivation variable and interest in visiting Lombok, each of them, have six indicators and three indicators.

This research is analyzed using SPSS 22 with classical assumption test (normality test, heteroscedasticity test, and multicollinearity test) to determine whether the data used has met the initial standard of the 
research. Data is analyzed using F-test and Ajd R test to determine the accuracy of model, while T-test is for hypothesis test. This research uses simple regression for total respondents, male respondents, and female respondents. The use of simple regression is conducted in three times of calculation for each type of respondents to see the result difference on them.

\section{Result and Discussion}

Descriptive Test

This research result shows that descriptive test of indicator in each variable, the highest mean is in indicator of experience to travel to new tourist attraction, while the lowest one is in indicator of social status.

Table 1. Descriptive Indicator Analysis

\begin{tabular}{|c|c|c|c|c|}
\hline Indicator & Mean & St. Deviasi & Min & M \\
\hline \multicolumn{5}{|l|}{ E-WOM } \\
\hline $\begin{array}{l}\text { Reading travel review of other } \\
\text { tourist }\end{array}$ & 7.0302 & 1.99218 & 1 & 10 \\
\hline $\begin{array}{l}\text { The right choice of tourist } \\
\text { attractions based on other trav- } \\
\text { eler reviews }\end{array}$ & 7.4642 & 1.71657 & 1 & 10 \\
\hline $\begin{array}{l}\text { Sharing experience with other } \\
\text { tourist }\end{array}$ & 6.5962 & 1.99412 & 2 & 10 \\
\hline $\begin{array}{l}\text { Collecting information from } \\
\text { online travel reviews }\end{array}$ & 6.1283 & 1.90165 & 2 & 10 \\
\hline $\begin{array}{l}\text { Fear of visiting before reading } \\
\text { other tourist reviews }\end{array}$ & 6.1283 & 2.27772 & 1 & 10 \\
\hline $\begin{array}{l}\text { Confidence in visiting tourist } \\
\text { attractions after reading tourist } \\
\text { reviews }\end{array}$ & 7.0755 & 1.78216 & 3 & 10 \\
\hline \multicolumn{5}{|l|}{ Travel Motivation } \\
\hline Using free time & 8.0226 & 1.62353 & 3 & 10 \\
\hline Recreation & 7.8906 & 1.68306 & 3 & 10 \\
\hline Social Status & 4.6642 & 2.31522 & 1 & 10 \\
\hline Shopping & 4.8377 & 2.29461 & 1 & 10 \\
\hline Experience to a New Place & 8.2075 & 1.57584 & 2 & 10 \\
\hline Adventure Desire & 8.2491 & 1.57581 & 2 & 10 \\
\hline
\end{tabular}




\section{Interest in Visiting Lombok}

I predict to go to Lombok $\begin{array}{llll}7.3132 & 2.25547 & 1 & 10\end{array}$

Lombok is the priority

$\begin{array}{llll}6.4642 & 2.04301 & 1 & 10\end{array}$

I plan to visit Lombok

7.083

2.13394

1 10

Model Accuracy Test

Model accuracy test in this research is conducted using F-test. The model accuracy test is carried out through simple regression test in each independent variable to dependent variable for total respondents. It is related to dummy variable in this research that becomes moderator variable, that is, gender variable.

Table 2. Model Accuracy Test

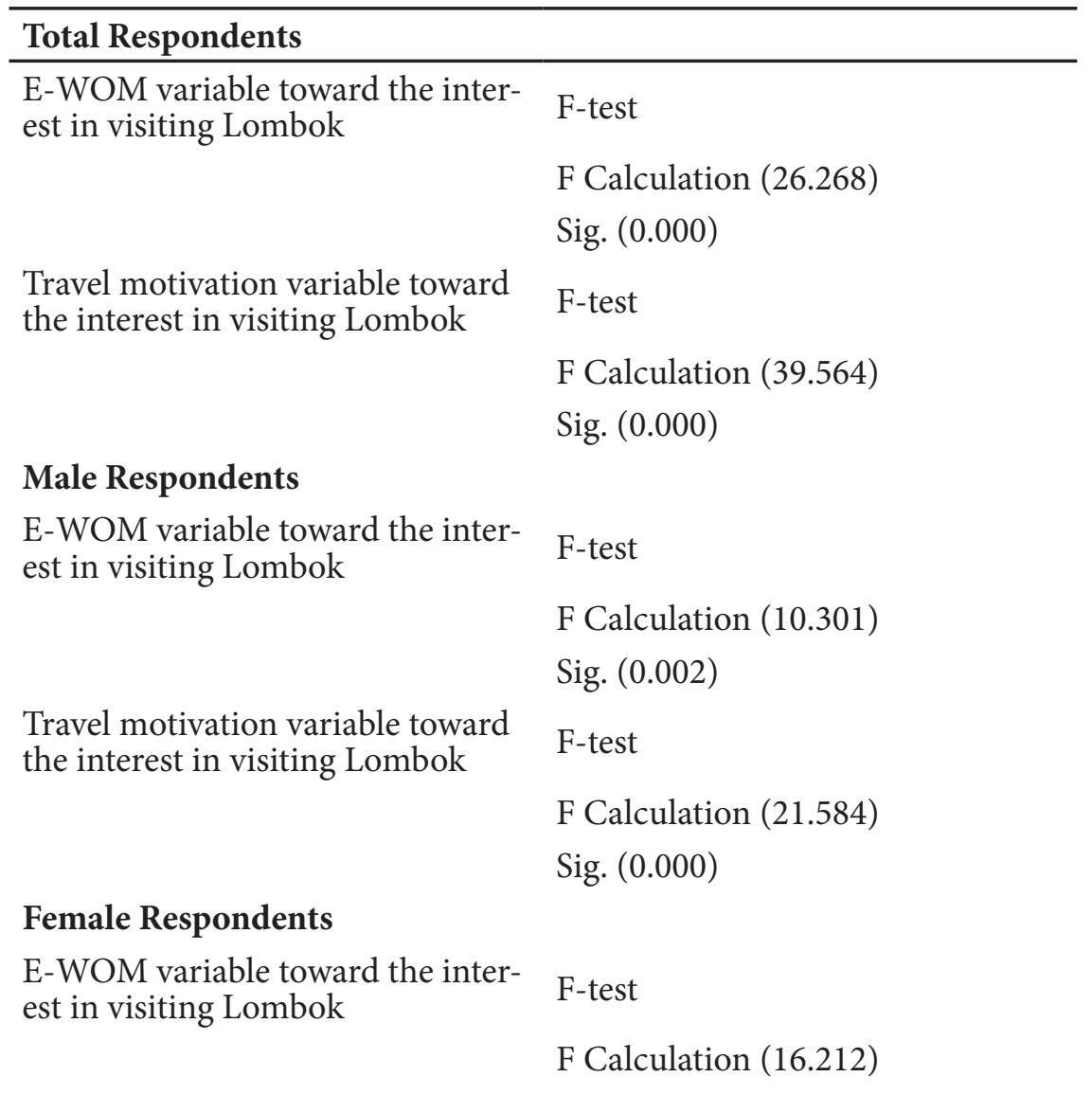


Sig. (0.000)

Travel motivation variable toward the interest in visiting Lombok

F-test

F Calculation (19.095)

Sig. (0.000)

The result of F-test in this research can be seen in table 2 above. It is seen that all types of respondents pass F-test because all sig $\mathrm{F}$ value below the limit of 0.05 , so this research is feasible to proceed to the next test.

Hypothesis Test

Table 3. Hypothesis Test

\begin{tabular}{lll}
\hline Respondent types & Hypothesis Test Result (Sig value) \\
\hline & $\begin{array}{l}\text { E-WOM >> interest in } \\
\text { visiting Lombok }\end{array}$ & $\begin{array}{l}\text { Travel motivation >> } \\
\text { interest in visiting } \\
\text { Lombok }\end{array}$ \\
\hline Total & 0.000 & 0.000 \\
Male & 0.002 & 0.000 \\
Female & 0.000 & 0.000 \\
\hline
\end{tabular}

Hypothesis test in this research obtains a result that e-WOM variable toward the interest in visiting Lombok for all types of respondents are below the upper limit value (0.05). It means that for all types of respondents in this research, e-WOM influences the interest in visiting Lombok. The research result shows that Electronic Word of Mouth influences the interest in visiting Lombok. The result is in line with a research conducted by (Tümer \& Alev, 2012). Meanwhile, the influence of travel motivation toward the interest in visiting Lombok is significant, where the research result is in line with the one conducted previously by (Hashemi, Jusoh, Kiumarsi, \& Mohammadi, 2015). On the other side, gender in this research result, that is, the perspective of men and women dealing the influence of e-WOM and travel motivation toward the interest in visiting Lombok have different perspective, which is in line with a research of (A Mohammed Abubakar et al., 2017; M.-J. Kim et al., 2013; Wong, Osman, Said, \& Paim, 2014).

Technology development gives changes in information search for tourists before making a visit to a destination; respondent of this research 
is technology-savvy generation. Therefore, it is undeniable that tourists will search for information through internet on e-WOM of tourists that ever visited the destination. Currently, information from e-WOM is really huge, so the information still becomes reference for tourists, and they believe in e-WOM created by fellow internet users. Information obtained by tourists from cyberspace is not all positive, so they can anticipate negative things happened to the tourists that create e-WOM. It is the thing that finally strengthens the position of e-WOM toward the interest in visiting Lombok.

Hypothesis test in this research provides a result that travel motivation variable the interest in visiting Lombok for all respondents of this research get significant value below the upper limit (0.05). Thus, it can be concluded that travel motivation variable gives significant influence toward the interest in visiting Lombok for all types of respondents in this research. Travel motivation becomes one of strong reasons for tourists in visiting destination due to the fact that respondents of this research is a generation that love to see new places, to adventure, and to spend free time.

\section{Moderation Test}

A moderation test is then conducted to test whether Gender variable is as mediator variable in this research. This moderation test compares value $\mathrm{R} 2$ on the test result of each type of respondents, and it is conducted twice in this research. First, R2 test is for the relation of e-WOM variable toward the interest in visiting Lombok. Second, R2 test is for the relation of motivation variable toward the interest in visiting Lombok. The First R2 Test (e-WOM toward the interest in visiting Lombok)

Table 4. R2 Value of e-WOM Variable toward the Interest in Visiting Lombok

\begin{tabular}{cc}
\hline Types of Respondents & $\mathrm{R} 2$ \\
\hline Male & $33.2 \%$ \\
Female & $28.9 \%$ \\
\hline
\end{tabular}

$\mathrm{R} 2$ test conducted on the relation of e-WOM variable toward the interest in visiting Lombok gives a result that R2 calculation value of male respondents is higher than $\mathrm{R} 2$ value of female respondents $(33.2 \%$ compared to 28.9\%). The result shows that e-WOM has significant 
influence toward the interest in visiting Lombok, with the strong influence on male respondents. In other words, men rely on e-WOM more in term of the interest in visiting Lombok compared to women. Men become more decision maker in travel plan than women, in terms of travel time and cost. Thus, men need to look for various kinds of information about tourist destination. Currently, huge information can be obtained from e-WOM, where there are a lot of tourists that have been travelling to tourist attractions and review them.

\section{Table 5. R2 Value of Travel Motivation Variable toward the Interest} in Visiting Lombok

\begin{tabular}{cc}
\hline Types of Respondents & R2 Value \\
\hline Male & $45.4 \%$ \\
Female & $31.1 \%$ \\
\hline
\end{tabular}

R2 test conducted on the relation of travel motivation variable toward the interest in visiting Lombok provides a result that $\mathrm{R} 2$ value of male respondents is higher than that of female respondents ( 45.15 compared to 31.1\%). It means that travel motivation of men is higher than women due to the fact that men like new things, especially about natural tourism, gaining experience on new places or learning new culture, which are interesting things for men. Thus, experience and desire on adventuring to new tourist attractions are more interesting form men than women.

\section{Conclusion}

The relation of e-WOM variable toward the interest in visiting Lombok has significant influence. The relation of travel motivation toward the interest in visiting Lombok has significant influence as well. The final result of this research states that there is difference between male prospective tourists and female prospective tourists in filtering information via e-WOM and travel motivation to Lombok in determining the interest in visiting Lombok. Those two independent variables give strong influence on male respondents than female respondents. 


\section{References}

Abubakar, A. M., \& Ilkan, M. (2016). Impact of online WOM on destination trust and intention to travel: A medical tourism perspective. Journal of Destination

Marketing and Management, 5(3), 192-201.

Abubakar, A. M., Ilkan, M., \& Al-tal, R. M. (2017). eWOM , revisit intention , destination trust and gender. Journal of Hospitality and Tourism Management, 31, 220-227.

Alkailani, M. (2016). Electronic Word Of Mouth (Ewom) And Its Effect On Consumers' Decisions To Buy Products And Services In Traditional Stores In Jordan. JCS, 24(4), 237-251.

Almuhrzi, H. M., \& Mohammed, A. (2017). Muslim perspectives on spiritual and religious travel beyond Hajj: Toward understanding motivations for Umrah travel in Oman. TourismManagement Perspectives.

Asih, S., \& Asih, S. (2015). Marketing Strategy Implementation in Developing Sharia Tourism in Indonesia. International Proceedings of Economics, 84, 133-137.

Auliya, Z. F., Umam, M. R. K., \& Prastiwi, S. K. (2017). Online Costumer Reviews ( OTRs ) dan Rating: New Era in Indonesia Online Marketing. EBBANK, 8(1), 89-98.

Bai, B., \& Hu, C. (2009). Affect, Travel Motivation, and Travel Intention: a Senior Market. Journal of Hospitality \& Tourism Research, (October 2014).

Battour, M., \& Ismail, M. N. (2014). The Role of Destination Attributes in Islamic Tourism. SHS Web of Conferences, 12, 556-564.

Bhuiyan, A. H., Siwar, C., Ismail, S. M., \& Islam, R. (2011). Potentials of Islamic Tourism : A Case Study of Malaysia on East Coast Economic Region. Australian Journal of Basic and Applied Sciences, 5(6), 1333-1340.

BPS. (2015). Kunjungan Wisatawan ke NTB. 
Chanin, O., Sriprasert, P., Rahman, H. A., \& Don, M. S. (2015). Guidelines on Halal Tourism Management in the Andaman Sea Coast of Thailand. Journal of Economics, Business and Management, 3(8), 791-794.

Chen, Y. C., Shang, R. A., \& Li, M. J. (2014). The effects of perceived relevance of travel blogs' content on the behavioral intention to visit a tourist destination. Computers in Human Behavior, 30, 787-799.

Chookaew, S., Chanin, O., Charatarawat, J., Sriprasert, P., \& Nimpaya, S. (2015). Increasing Halal Tourism Potential at Andaman Gulf in Thailand for Muslim Country. Journal of Economics, Business and Management, 3(7), 739-741.

Chou, S. Y. (2012). Online Reviews and Pre-Purchase Cognitive Dissonance : A Theoretical Framework and Research Propositions. Journal of Emerging Trends in Computing and Information Sciences, 3(2), 199-204.

Dellarocas, C. (2003). The Digitization of Word of Mouth: Promise and Challenges of Online Feedback Mechanisms. Management Science, 49(10), 1407-1424.

di Pietro, L., \& Pantano, E. (2013). Social network influences on young tourists: An exploratory analysis of determinants of the purchasing intention. Journal of Direct, Data and Digital Marketing Practice, 15(1), 4-19.

Duman, T. (2011). Value of Islamic tourism offering: Perspectives from the Turkish experience. World Islamic Tourism Forum (WITF, 2011), Kuala Lumpur, (July), 1-9.

Ferdinand, A. (2014). Metode Penelitian Manajemen (V). Semarang: Badan Penerbit Universitas Diponegoro.

Filieri, R. (2016). What makes an online consumer review trustworthy? Annals of Tourism Research, 58, 46-64.

Geng, J., Long, R., Chen, H., \& Li, W. (2017). Resources , Conservation \& Recycling Exploring the motivation-behavior gap in urban residents ' green travel behavior : A theoretical and empirical study. Resources, Conservation \& Recycling, 125(April), 282-292. 
Hashemi, S. M., Jusoh, J., Kiumarsi, S., \& Mohammadi, S. (2015). Influence Factors of Spa and Wellness Tourism on Revisit Intention: the Mediating Role of International Tourist Motivation and Tourist Satisfaction. Journal of Research -GRANTHAALAYAH, 3(7), 1-11.

Jaelani, A. (2016). Halal tourism industry in Indonesia: Potential and prospects. Munich Personal RePEc Archive, (72700).

Jaelani, A. (2017a). Halal tourism industry in Indonesia: Potential and prospects. Business, 7(76235), 25-34.

Jaelani, A. (2017b). Industri wisata halal di Indonesia: Potensi dan prospek. Munich Personal RePEc Archive, (January).

Jalilvand, M. R., Ebrahimi, A., \& Samiei, N. (2013). Electronic Word of Mouth Effects on Tourists' Attitudes Toward Islamic Destinations and Travel Intention: An Empirical Study in Iran. Procedia - Social and Behavioral Sciences, 81(2006), 484-489.

Karakowsky, L., \& Elangovan, a. R. (2001). Risky Decision Making in Mixed-Gender Teams: Whose Risk Tolerance Matters? Small Group Research, 32(1), 94-111.

Khan, M. J., Chelliah, S., \& Ahmed, S. (2017). Factors influencing destination image and visit intention among young women travellers: role of travel motivation, perceived risks, and travel constraints. Asia Pacific Journal of Tourism Research, 0(0), 1-17.

Kim, D., Jang, S. (Shawn), \& Adler, H. (2015). What drives café customers to spread eWOM? International Journal of Contemporary Hospitality Management, 27(2), 261-282.

Kim, M.-J., Lee, C.-K., \& Chung, N. (2013). Investigating the Role of Trust and Gender in Online Tourism Shopping in South Korea. Journal of Hospitality \& Tourism Research, 37(3), 377-401.

Konu, H., \& Laukkanen, T. (2009). Roles of Motivation Factors in Predicting Tourists' Intentions to Make Wellbeing Holidays - A Finnish Case. ANZMAC, 1-9.

Kreis, H., \& Gottschalk, S. A. (2015). Relating eWOM Motives to eWOM Channel Choice - Why Do We Post Where We Do ? Ewom Channel 
Choice, (October), 406-430.

Lee, J. H., Kim, H. D., Ko, Y. J., \& Sagas, M. (2011). The influence of service quality on satisfaction and intention: A gender segmentation strategy. Sport Management Review, 14(1), 54-63.

Lee, M., \& Youn, S. (2009). Electronic word of mouth (eWOM): How eWOM platforms influence consumer product judgement. International Journal of Advertising, 28(3), 473-499.

Lin, J.-H. (2014). Identifying Gender Differences in Destination Decision Making. Journal of Tourism and Recreation, 1(1), 1-11.

Lu, J., Hung, K., Wang, L., Schuett, M. A., \& Hu, L. (2016). Do perceptions of time affect outbound-travel motivations and intention? An investigation among Chinese seniors. Tourism Management, 53, $1-12$.

Mastercard, \& CrescentRating. (2016). Global Muslim Travel Index 2016.

Meyers-Levy, J., \& Loken, B. (2015). Revisiting gender differences: What we know and what lies ahead. Journal of Consumer Psychology, 25(1), 129-149.

Mohsin, A., Ramli, N., \&J Alkhulayfi, B. A. (2016). Halal tourism: Emerging opportunities. Tourism Management Perspectives, 19, 137-143.

NTB Bisa Bangga, Jumlah Kunjungan Wisata Penuhi Target 3 Juta di 2016. (2016). KickerNews.today.

Prabowo, S., Rahman, A. A., Rahman, S. A., \& Samah, A. A. (2015). Revealing factors hindering halal certification in East Kalimantan Indonesia. Journal of Islamic Marketing Vol., 6(2), 268-291.

Razzaq, S., Hall, C. M., \& Prayag, G. (2016). The capacity of New Zealand to accommodate the halal tourism market - Or not. Tourism Management Perspectives, 18, 92-97.

Reimer, T., \& Benkenstein, M. (2016). When good WOM hurts and bad WOM gains: The effect of untrustworthy online reviews. Journal of Business Research, 69(12), 5993-6001.

Reza Jalilvand, M., \& Samiei, N. (2012). The impact of electronic word of 
mouth on a tourism destination choice. Internet Research, 22(5), 591-612.

Shao, K. (2012). The Effects of Controversial Reviews on Product Sales Performance: The Mediating Role of the Volume of Word of Mouth. International Journal of Marketing Studies, 4(4), 32-39.

Shin, D., Song, J. H., \& Biswas, A. (2014). Electronic word-of-mouth (eWOM) generation in new media platforms: The role of regulatory jfocus and collective dissonance. Marketing Letters, 25(2), 153-165.

Ting, C. S., Chiu, L. K., \& Kayat, K. (2015). Travel Lifestyles and Outbound Tourism Intentions of Young Malaysians. American Journal of Tourism Management, 4(2), 40-42.

Tsai, L. M., Sakulsinlapakorn, K., \& Council, T. (2016). Exploring Tourists' Push and Pull Travel Motivations to Participate in Songkran Festival in Thailand as a Tourist Destination: A Case of Taiwanese Visitors. Journal of Tourism jand Hospitality Management, 4(5), 183-197.

Tseng, C.-H., Kou, H.-C., \& Chen, J.-M. (2014). Do Types of Virtual Community Matter for the Effects of online Advertisement and Electronic Words of Mouth? Marketing Review (Xing Xiao Ping Lun), 11(1), 28-50.

Tümer, E., \& Alev, K. (2012). Revisit Intention of Consumer Electronics Retailers : Effects of Customers 'E motion, Technology Orientation and WOM Influence. Procedia - Social and Behavioral Sciences, 41, $65-73$.

Vuuren, C. Van, \& Slabbert, E. (2011). Travel Motivation and Behaviour of Tourists to a South African Resort. International Conference on Tourism and Management Studies - Algarve 2011, I, 295-304.

Wang, P. (2015). Exploring the influence of electronic word-of-mouth on tourists' visit intention. Journal of Systems and Information Technology, 17(4), 381-395.

Whang, H., Yong, S., \& Ko, E. (2015). Pop culture, destination images , and visit intentions : Theory and research on travel motivations of Chinese and Russian tourists. Journal of Business Research. 
Wong, Y., Osman, S., Said, A., \& Paim, L. (2014). Moderating Effect of Gender in Repatronage Behavioral Intention: The Role of Personal Characteristics. Asian Social Science, 10(1), 106-116. 